\title{
Diversity and antimicrobial resistance of Salmonella isolated from swines feces and carcasses
}

\author{
Roberta Torres de Melo ${ }^{1,2}$; Eliane Pereira Mendonça ${ }^{3}$; \\ Guilherme Paz Monteiro ${ }^{4}$; Edson Campos Valadares Junior ${ }^{2}$; \\ Adélia Rodrigues Guimarães ${ }^{2}$; Raquelline Figueiredo Bráz²; \\ Fernanda Aparecida Longato dos Santos ${ }^{2}$; \\ Phelipe Augusto Borba Martins Peres ${ }^{4}$; Ana Carolina de Souza Santos 3 ; \\ Maria Eduarda de Lourdes Vaz3; Daise Aparecida Rossi ${ }^{2,4}$
}

\begin{abstract}
The aim of this study was to determine the most frequent Salmonella serovars in swine feces in the farm, piggery's waiting slaughterhouse and after in their carcasses during slaughter, as well as their antimicrobial resistance profiles. Eighty six strains of Salmonella spp. were used, they were previously isolated from three different lots in different collections. The identification of serovars was done by serotyping and the resistance to antimicrobial agents was determined by disc diffusion. A variety of serovars was observed, and the 86 strains were serologically identified as: 28 (32.55\%) S. Typhimurium, 20 (23.26\%) S. Agona, 17 (19.77\%) S. Infantis, $6(6.98 \%)$ S. Panama, and $15(17.44 \%)$ S. Minnesota. The diversity of serovars indicated that different factors influence the infection of finishing pigs and the persistence of microorganisms in the carcass after slaughter of these animals. More than $50 \%$ of the isolates were resistant to nine of the 11 tested antibiotics. The drugs that microorganisms had the highest percentages of sensitivity were sulphazotrim and norfloxacin, $22.1 \%$ and $14 \%$, respectively. S. Typhimurium serovar was the most isolated, including in the carcasses, and also showed the largest difference in antimicrobial resistance when compared to other serovars. The profile of multidrug resistance observed in this study highlights to the necessity of a judicious observation of antimicrobial resistance in zoonotic foodborne bacteria.
\end{abstract}

Keywords: Salmonellosis, Antibiogram, Serotyping, Multiresistance.

\footnotetext{
${ }^{1}$ Rua Ceará s/n Bloco 2D Sala 43 - Bairro Umuarama - Cep 38405-315 - Universidade Federal de Uberlândia (UFU) - Uberlândia/MG-(34) 3213-2319. E-mail: roberta-melo@hotmail.com

${ }^{2}$ Faculdade de Medicina Veterinária (UFU).

3 Universidade de Uberaba (UNIUBE).

${ }^{4}$ Programa de Pós-Graduação em Ciências Veterinárias (UFU).
} 


\title{
Diversidade e resistência aos antimicrobianos de Salmonella isoladas de fezes e carcaças de suínos
}

\begin{abstract}
RESUMO
Objetivou-se determinar os sorovares de Salmonella mais freqüentes em fezes de suínos na granja de terminação, pocilga de espera do frigorífico e em suas carcaças durante o abate, assim como, seus perfis de resistência aos antimicrobianos. Utilizou-se 86 cepas de Salmonella spp previamente isoladas de três lotes diferentes em coletas distintas. A identificação dos sorovares foi realizada por meio de sorotipificação e a resistência aos antimicrobianos foi determinada pela técnica de difusão de discos. Foi observada uma multiplicidade de sorovares, sendo as 86 cepas identificadas sorologicamente como: 28 (32,55\%) S. Typhimurium, 20 (23,26\%), S. Agona, 17 (19,77\%) S. Infantis, 6 (6,98\%) S. Panama, e 15 $(17,44 \%)$ S. Minnesota. A diversidade de sorovares indicou que diferentes fatores influenciam na infecção de suínos em terminação e na persistência do microrganismo na carcaça destes animais após o abate. Mais de 50\% dos isolados apresentaram resistência a nove dos 11 antibióticos testados. As drogas as quais os microrganismos apresentaram os maiores percentuais de sensibilidade foram o sulfazotrim e a norfloxacina, $22,1 \%$ e $14 \%$, respectivamente. $S$. Typhimurium foi o sorovar mais isolado, inclusive nas carcaças, e também o que demonstrou maior diferença quanto à resistência aos antimicrobianos, quando comparado aos outros sorovares. O perfil de multirresistência observado neste estudo alerta para a necessidade de vigilância e monitoramento sistemático da resistência aos antimicrobianos em bactérias zoonóticas transmitidas pelos alimentos.
\end{abstract}

Palavras-chave: Salmonelose, antibiograma, sorotipagem, multirresistência.

$$
* * *
$$

\section{Introduction}

Salmonellosis is one of the leading causes of foodborne gastroenteritis in humans worldwide, and is considered to be an important public health problem in both, industrialized and developing countries (EFSA, 2010; LOUREIRO et al., 2010).

The diversification of the industrial production of pork and the commercial exchange of animals and their derivatives for human consumption may be important disseminators of Salmonella spp. in the food chain. Thus, the presence of this microorganism in the production process 
represents an important sanitary barrier to trade food of animal origin and their by-products (SEIXAS et al., 2009).

Bacteria of the genus Salmonella are isolated worldwide, however, in areas of intensive breeding, especially of swine and birds, reports are even more frequent (OIE, 2004). The increase of the density and the indiscriminate use of antibiotics, inserted in the process of producing foods of animal origin, can act as selection pressure for some serovars and for their resistance to antimicrobials.

According to Wray; Sojka (1977) it is widely accepted that animals infected with Salmonella are the major sources of infection for other animals and humans. Thus, constant monitoring with identification of serovars and establishment of the epidemiological relationship of these along the production chain is of great importance.

Thus, we aimed to know which serovars of Salmonella spp. are infecting the pigs at the termination after transport to the slaughterhouse and in their carcasses after slaughter, as well as establish the antimicrobial resistance profile of these strains in order to contribute to a better understanding of the epidemiology of these microorganisms and provide information that may assist in the implementation of measures for the production of safe food.

\section{Material and methods}

A total of 86 strains of Salmonella spp. isolated from swine feces housed in the finishing farm, in the holding pens and from their carcasses during slaughter were used. The collection in the carcasses (after depilation, evisceration and in mesenteric lymph nodes) were performed in a non-exporter slaughterhouse under municipal inspection in the state of Minas Gerais.

The strains were previously isolated by (PACHECO, 2009) and serotyping was carried out in the Setor de Enterobactérias da Fundação Osvaldo Cruz (FIOCRUZ). 
The technique used for the antimicrobial resistance was the disk diffusion test according to the protocol described by the National Committee for Clinical Laboratory Standards (NCCLS, 2002). The antibiotics used for the test were: amoxicillin $10 \mu \mathrm{g}$, norfloxacin $10 \mu \mathrm{g}$, gentamicin $10 \mu \mathrm{g}$, erythromycin $15 \mu \mathrm{g}$, nalidixic

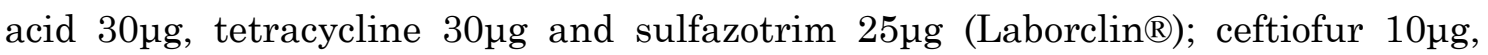
enrofloxacin $5 \mu \mathrm{g}$ and lincomycin $2 \mu \mathrm{g}$ (Sensifar ${ }^{\circledR}$ ). The strain E. coli ATCC 25922 was used as a control. The plates were incubated at $37^{\circ} \mathrm{C}$ for 18 to 20 hours, and then the sensitivity halos (in millimeters) were measured using a pachymeter and subsequent classification of the microorganism as sensitive, intermediate or resistant to the tested antimicrobial.

The antimicrobial resistance profile determined for the different serovars was compared using the Chi-square test with $95 \%$ of confidence. The calculations were performed using the Biostat 5.0 program (AYRES, 2007).

\section{Results and discussion}

The 86 strains of Salmonella spp. were identified serologically as: 28 (32.55\%) S. Typhimurium, 20 (23.26\%) S. Agona, 17 (19.77\%) S. Infantis, 6 (6.98\%) S. Panama and 15 (17.44\%) S. Minnesota.

The diversity of serovars identified in feces and swine carcasses, with a higher incidence of $S$. Typhimuirium was also observed in another study. Bessa et al. (2004), in Rio Grande do Sul, identified 26 different serovars in 226 Salmonella isolates from 300 pigs slaughtered in three slaughterhouses. The most prevalent serovars were Typhimurium (24.3\%), Agona (19.9\%), Derby (13.2\%) and Bredeney (12\%). S. Panama and S. Infantis were also identified, but less frequently, $5.75 \%$ and $0.88 \%$, respectively.

S. Typhimurium, S. Agona and $S$. Infantis were the most isolated serotypes in this study. According to Loureiro et al. (2010), these serovars are associated with cases of human salmonellosis in Brazil. Serovar $S$. Typhimurium was also the most isolated in swine samples in São Paulo and Rio de Janeiro by Filho (2014) and Cabral et al. (2017), respectively. In the 
United States, the three serotypes most frequently isolated in humans with salmonellosis are Typhimurium, Enteritidis and Newport, denoting the potential risk of these agents (CDC, 2006).

$S$. Infantis and $S$. Agona are also recognized for their pathogenic potential, which, in addition to the gastroenteric condition, may cause septicemia in young animals and humans, especially in cases of severe infections in children (TESSMANN et al., 2008).

All serovars were isolated both in the farm and in the slaughterhouse, except for $S$. Panama, which was not found in fecal samples collected at the termination farm, as shown in Table 1. It is possible that the source of contamination of carcasses by this serovar is equipment or instruments used at slaughter and is not related to prior infection of the animals.

Considering only the fecal samples, $S$. Agona was the most identified, but in the samples from animals slaughtered there was a higher incidence of $S$. Typhimurium. This serovar is one of the most involved in sporadic cases and outbreaks of gastroenteritis in Brazil (FREITAS, 2011). The number of isolates of $S$. Typhimurium in animals still housed on the farm after transport to the slaughterhouse and on their carcasses during slaughter shows that there is an amplification in the number of isolates during slaughter.

Table 1. Salmonella serovars isolated in finishing farm, holding pens and during the slaughtering stages of swines

\begin{tabular}{lllll}
\hline Serovar & Finishing farm & $\begin{array}{l}\text { Holding } \\
\text { (slaughterhouse) }\end{array}$ & $\begin{array}{l}\text { pens } \\
\text { stages } \\
\text { (slaughterhouse) }\end{array}$ & TOTAL \\
\hline S. Typhimurium & $\mathrm{N} \mathrm{( \% )}$ & $\mathrm{N}(\%)$ & $\mathrm{N} \mathrm{( \% )}$ & $\mathrm{N}(\%)$ \\
S. Agona & $8(9.30)$ & $5(5.81)$ & $15(17.44)$ & $28(32.56)$ \\
S. Infantis & $9(10.46)$ & $6(6.98)$ & $5(5.81)$ & $20(23.25)$ \\
S. Minnesota & $4(4.65)$ & $5(5.81)$ & $8(9.30)$ & $17(19.77)$ \\
S. Panama & $6(6.98)$ & $6(6.98)$ & $3(3.49)$ & $6(6.98)$ \\
\hline TOTAL & -- & $1(1.16)$ & $5(5.81)$ & $86(100)$ \\
N (\%) - number of positive samples of each serovar and percentage of total samples identified as \\
Salmonella spp.
\end{tabular}


The increase in the number of isolates in the carcasses was observed for $S$. Typhimurium and $S$. Infantis serovars. It is likely that strains of these serovars are more adapted to adverse environmental conditions, such as those occurring during slaughter. O'Connor et al. (2009) verified that $S$. Typhimurium may possess a gene involved in the coding of a $\mathrm{Mg}^{2+}$ carrier protein, which acts to protect the cell membrane integrity exposed to high temperatures, conferring greater thermotolerance.

The increase in the number of isolates in $S$. Typhimurium and $S$. Infantis during slaughter allows us to infer that probably animals with faecal positivity contribute to a contaminated final product. It also demonstrates the need for control measures in the field to reduce the presence of these pathogens in the intestinal contents of the animals and consequent decrease of the same during the stages of slaughter.

Although S. Agona was isolated from both, live animals and carcasses, it was not identified after evisceration (data not shown). Postslaughter processing conditions are likely to have limited their survival and multiplication, and this partly explains their absence in carcasses after sawing.

$S$. Minnesota showed a reduction in the number of isolates during the slaughtering stages. Probably this serovar suffers injury during the processing of slaughter, disappearing or remaining in numbers not detectable in the technique of traditional isolation.

The presence of only one isolate of $S$. Panama in live animal feces as opposed to the five carcass isolates demonstrates that carcass contamination during slaughter stages is probably not related to the previous infection of the animals.

The multiresistance of antibiotics in the Salmonella genus is a worldwide trend and is in line with the present study, since most isolates have demonstrated this profile. Of the studied isolates, more than 50\% presented resistance to nine of the 11 tested antibiotics. The drugs with the 
highest sensitivity percentages were sulfazotrim and norfloxacin, $22.1 \%$ and $14 \%$, respectively. However, even for these antimicrobials, the intermediate sensitivity indices observed were considered high, which may indicate the development of resistance in the medium term.

In the PREBAF report (BRASIL, 2008) on the monitoring of antimicrobial resistance of Salmonella and Enterococcus isolates from chicken carcasses, the treatment of enteropathogen infections using fluoroquinolones and third-generation cephalosporins has "a bleak outlook". The resistance profile observed in this study confirms that this is a reality also for infection caused by Salmonella isolated from swine. No strain was sensitive to ceftiofur, which is a third generation cephalosporin, and only four $(4.7 \%)$ of the isolates were sensitive to enrofloxacin (fluorquinolone). Norfloxacin (second generation fluorquinolone), although the second most effective drug in this study, had only $12(14.0 \%)$ of the isolates classified as sensitive.

Several authors and organizations have reported a significant increase in the identification of microorganisms isolated from animals and foods that are resistant to antimicrobials (HOPKINS et al., 2010). Many authors report that this occurrence is particularly associated with the use of therapeutic and subtherapeutic doses of antibiotics in animals and the indiscriminate use of antimicrobials in human medicine, both in hospitals and in the community (BEGUM et al., 2010).

The resistance determined for each of the serovars showed that there was variation of antimicrobial resistance between serovars when analyzed by the chi-square test. 
Table 2. Antimicrobial resistance of Salmonella isolated from swine feces and carcasses

\begin{tabular}{llllll}
\hline & \multicolumn{2}{l}{ Serovars $(\mathrm{N}=86)$} & & \\
\cline { 2 - 5 } Antimicrobial & Typhimurium & Agona & Infantis & Panama & Minnesota \\
\cline { 2 - 6 } & $\mathrm{N}=28$ & $\mathrm{~N}=20$ & $\mathrm{~N}=17$ & $\mathrm{~N}=6$ & $\mathrm{~N}=15$ \\
\hline Amoxicillin & $27(96.4)$ & $10(50.0)$ & $15(88.2)$ & $5(83.3)$ & $13(86.7)$ \\
Gentamicin & $27(96.4)$ & $14(70.0)$ & $15(88.2)$ & $6(100.0)$ & $13(86.7)$ \\
Norfloxacin & $20(71.4)$ & $7(35.0)$ & $11(64.7)$ & $6(100.0)$ & $4(26.7)$ \\
Neomycin & $28(100.0)$ & $14(70.0)$ & $15(88.2)$ & $6(100.0)$ & $14(93.3)$ \\
Lincomycin & $28(100.0)$ & $20(100.0)$ & $17(100.0)$ & $6(100.0)$ & $15(100.0)$ \\
Ceftiofur & $28(100.0)$ & $20(100.0)$ & $17(100.0)$ & $6(100.0)$ & $13(86.7)$ \\
Tetracycline & $27(96.4)$ & $16(80.0)$ & $17(100.0)$ & $6(100.0)$ & $15(100.0)$ \\
Sulfazotrim & 0 & $2(10.0)$ & $4(23.5)$ & 0 & $8(53.3)$ \\
Erythromycin & $26(92.9)$ & $15(75.0)$ & $17(100.0)$ & $6(100.0)$ & $15(100.0)$ \\
Nalidixic Acid & $18(64.3)$ & $17(85.0)$ & $15(88.2)$ & $6(100.0)$ & $13(86.7)$ \\
Enrofloxacin & $28(100.0)$ & $14(70.0)$ & $12(70.6)$ & $6(100.0)$ & $5(33.33)$ \\
\hline N & &
\end{tabular}

$\mathrm{N}(\%)$ - number of samples and percentage in relation to the specified serovar.

$S$. Typhimurium was the serovar that showed the most difference in relation to the others studied, showing a higher resistance to amoxicillin, neomycin and enrofloxacin when compared to $S$. Agona $(\mathrm{P}<0.01)$; to enrofloxacin compared to Minnesota serovars $(\mathrm{P}<0.01)$ and Infantis $(\mathrm{P}$ $<0.05)$; and norfloxacin compared to Minnesota $(\mathrm{P}<0.05)$.

$S$. Typhimurium was classified as multidrug resistant because of the resistance to three or more antimicrobial classes. All isolates of this serovar demonstrated resistance to neomycin (aminoglycoside), lincomycin (lincosamide), ceftiofur (cephalosporin) and enrofloxacin (fluorquinolone) and more than 96\% showed resistance to amoxicillin (betalactam), gentamicin (aminoglycoside) and tetracycline. However, all were sensitive to sulfazotrim. In this study, the resistance of serovar Typhimurium to sulfazotrim was significantly lower than that observed for Infantis $(\mathrm{P}<0.05)$ and Minnesota $(\mathrm{P}<0.01)$ serovars.

The resistance to tetracycline in $96.4 \%$ of $S$. Typhimurium isolates was higher than that observed in other studies carried out in Brazil on swine samples. Resistance to this antimicrobial was also observed in $41.67 \%$ of strains isolated from fresh sausage by Spricigo (2008). Studies in Europe with porcine isolates marketed in the member countries showed lower 
resistance than those of this study for $S$. Typhimurium, with indices varying from $36.05 \%$ to $59 \%$ (EFSA, 2006; EFSA, 2008). The increase in resistance levels to ampicillin, tetracycline and chloramphenicol since 1996 in Salmonella isolated from humans, pigs and chickens characterizes the emergence of multi-resistant S. Typhimurium (BEGUM et al., 2010). However, this author reports that isolates with these characteristics are also resistant to the sulfa and trimethoprim association (sulfazotrim), which was not observed in this study.

There was no difference between the resistance determined in the serovar Agona compared to the other antimicrobial isolates: gentamicin, lincomycin, ceftiofur, tetracycline, erythromycin, nalidixic acid and enrofloxacin. However, this serovar showed a lower number of isolates resistant to amoxicillin and neomycin compared to serovar Typhimurium ( $\mathrm{P}$ $<0.01$ ), norfloxacin compared to Panama ( $\mathrm{P}<0.01)$; and sulfazotrim compared to Minnesota $(\mathrm{P}<0.05)$.

Despite being frequently isolated from food and environment and in some clinical samples, there are few reports on resistance or multidrug resistance in $S$. Agona. In this study, this serovar showed the lowest percentages of isolates resistant to the drugs tested.

S. Panama presented a profile similar to that observed for serovar Typhimurium, with $100 \%$ of resistance to nine of the antimicrobials tested and $83.3 \%$ of isolates resistant to amoxicillin, but $100 \%$ sensitive to sulfazotrim. Regarding the other serovars, S. Panama showed to be more resistant to enrofloxacin when compared to $S$. Minnesota $(\mathrm{P}<0.05)$ and norfloxacin in relation to serovar Agona $(\mathrm{P}<0.01)$. There was less resistance to sulfazotrim by the isolates when compared to those identified as $S$. Minnesota $(\mathrm{P}<0.05)$.

The resistance profile determined for the serovar Panama in this study is different from that observed by Castagna et al., (2004) in isolates of 
feces and mesenteric lymph nodes of pigs at slaughter in three slaughterhouses in southern Brazil.

Isolates identified as $S$. Infantis presented a lower percentage of resistance to enrofloxacin compared to serovar Typhimurium, but a higher number of isolates resistant to sulfazotrim compared to this same serovar $(\mathrm{P}$ $<0.05)$. All isolates were resistant to lincomycin, ceftiofur, tetracycline and erythromycin. The antimicrobial resistance of $S$. Infantis in this study was higher than that observed by Tessmann et al. (2008). These authors determined sensitivity of $100 \%$ and $43 \%$ for nalidixic acid and tetracycline, respectively, in $S$. Infantis isolated from pork cuts at Pelotas, RS.

The isolates identified as $S$. Minnesota were less resistant to norfloxacin compared to $S$. Typhimurium and enrofloxacin compared to $S$. Panama $(\mathrm{P}<0.05)$, but presented higher resistance to sulfazotrim compared to serovar Typhimurium $(\mathrm{P}<0.01)$. $S$. Minnesota is considered an emerging etiologic agent of human salmonellosis (EFSA, 2008).

In Brazil, the use of antimicrobials avilamycin, bacitracin, chlorhexidine, flavomycin, chlorohydroxyquinoline, tylosin, lincomycin and erythromycin as feed additives in finishing pigs is permitted (BRASIL, 1998). Of these, the last two were tested in this study. With the exception of $8.1 \%$ of the isolates of $S$. Typhimurium and $25 \%$ of $S$. Agona, which presented a profile classified as intermediate to erythromycin, the other isolates were $100 \%$ resistant to these drugs.

The results of this study show that, independent of the differences identified among serovars for some antimicrobials, the isolates presented a multiresistance profile, especially for those most used in clinical treatment in farms such as enrofloxacin, lincomycin, amoxicillin, tetracycline, erythromycin, norfloxacin, ceftiofur and sulfazotrim, and the observed differences are likely to be more associated to the series than to the serovar. Resistance is worrying and demonstrates the need to reduce the use of antimicrobials in animal production as a way to reduce the selection 
pressure to which these microorganisms are subjected. It also warns of the difficulties that may occur in the treatment of extraintestinal infections and in groups at risk, where antibiotic therapy and the need to monitor antimicrobial resistance in foodborne zoonotic bacteria are required.

Initiatives such as the monitoring of Salmonella resistance isolated from frozen chicken carcasses throughout the country carried out by ANVISA in the PREBAF project (BRASIL, 2008) provide important data. The information generated allows the adequate visualization of the problem to promote the implementation of effective control measures.

\section{Conclusion}

The most identified serovars were $S$. Typhimurium, $S$. Agona and $S$. Infantis. The multiplicity of Salmonella serovars identified at the analyzed points of the productive process indicates that different factors influence the infection of finishing pigs and their presence and persistence in the carcass of these animals after slaughter. This reinforces the importance of a rigorous monitoring that allows to subsidize actions that promote the adequate control of these pathogens from the farm to the steps of slaughter and guarantee the health of the consumer.

The strains showed higher resistance to lincomycin and ceftiofur. The pattern of multidrug resistance determined for different serovars alerts to the need for implementation of systematic monitoring of the antimicrobial response in foodborne zoonotic bacteria.

\section{References}

AYRES, M. 1.; AYRES Jr, M.; AYRES, D. L.; SANTOS, A. A. S. BioEstat: aplicações estatísticas nas áreas das ciências biológicas e médicas. Belém: Sociedade Civil Mamirauá: MCT-CNPq, 2007. 
BEGUM, K.; REZA, T. A.; HAQUE, M.; HOSSAIN, A.; HASSAN, F. M. K.; HASAN, S. N.; AKHTER, N.; AHMED, A.; BARUA, U. Isolation, identification and antibiotic resistance pattern of Salmonella spp. from chicken eggs, intestines and environmental samples. Bangladesh Pharmaceutical Journal, Bangladesh, v. 13, n. 1, p. 23-27, 2010.

BESSA, M.C; COSTA, M.; CARDOSO, M. Prevalência de Salmonella sp. em suínos abatidos em frigoríficos do Rio Grande do Sul. Pesquisa Veterinária Brasileira, Rio de Janeiro, v.24, p.80-84, 2004.

BRASIL. Secretaria de Defesa Agropecuária. Of. Circular DFPA nº 047/98, 1998. Departamento de Fiscalização de Insumos Agropecuários (DFIP). Available in: <http://extranet.agricultura.gov.br/sislegis-consulta>. Accessed in: oct. 2011.

BRASIL. Ministério da Saúde. Agência Nacional de Vigilância Sanitária - Anvisa. Relatório do monitoramento da prevalência e do perfil de suscetibilidade aos antimicrobianos em enterococos e salmonelas isolados de carcaças de frango congeladas comercializadas no Brasil. Programa Nacional de Monitoramento da Prevalência e da Resistência Bacteriana em Frango (PREBAF). Janeiro/2008.

CABRAL, C. C.; PANZENhAGEN, P. H. N.; DELGADO, K. F.; SIlVA, G. R. A.; RODRIGUES, D. P.; FRANCO, R. M.; CONTE-JUNIOR, C. A. Contamination of Carcasses and Utensils in Small Swine Slaughterhouses by Salmonella in the Northwestern Region of the State of Rio de Janeiro, Brazil. Journal of Food Protection; v. 80, n. 7, p. 1128-1132, 2017.

CASTAGNA, S. M. F.; SCHWARZ, C. W.; CARDOSO, M. Presença de Salmonella spp. no trato intestinal e em tonsilas/linfonodos submandibulares de suínos ao abate. Arquivo Brasileiro de Medicina Veterinária e Zootecnia, Belo Horizonte, v. 56, n. 3, p. 300-306, 2004. 
CENTER FOR DISEASE CONTROL. Preliminary foodnet data on the incidence of infection with pathogens transmitted commonly through foods - 10 States, United States, 2005. Morbidity and Mortality Weekly Report, v. 55, n. 14, p. 392-395, 2006.

EUROPEAN FOOD SAFETY AUTHORITY - Report of the task force of zoonoses data collection including a proposal for a harmonized monitoring scheme of antimicrobial resistance in Salmonella in fowl (Gallus gallus), turkeys and pigs and Campylobacter jejuni and C. coli in broilers. The EFSA Journal, Italy, v. 403, p. 1-16, 2006.

EUROPEAN FOOD SAFETY AUTHORITY - For citation purposes: Scientific Opinion of the Panel on Biological Hazards on a request from the European Food Safety Authority on foodborne antimicrobial resistance as a biological hazard. The EFSA Journal, Italy, n. 765, p. 1-87, 2008.

EUROPEAN FOOD SAFETY AUTHORITY - Analysis of the baseline survey on the prevalence of Campylobacter in broiler batches and of Campylobacter and Salmonella on broiler carcasses in the EUA, 2008. The EFSA Journal, Italy, v. 8, n. 3, p. 1503, 2010.

FILHO, J. B. P. G. Resistência antimicrobiana e prevalência de sorovares de Salmonella spp. isolados de fezes e linfonodos de suínos 2014. $67 \mathrm{f}$. /. Dissertation (Master degree) - Universidade Estadual Paulista "Júlio de Mesquita Filho", Faculdade de Medicina Veterinária e Zootecnia, Botucatu, SP, 2014.

FREITAS, J. Evolução de sorovares - Modelo de banco de cepas. Anais do seminário internacional de salmonelose aviária. Rio de Janeiro. RJ. 2011.

HOPKINS, K. L.; KIRCHNER, M.; GUERRA, B.; GRANIER, S. A.; LUCARELLI, C.; PORRERO, M. C.; JAKUBCZAK, A.; ThRELFALL, E. J.; MEVIUS, D. J. Multiresistant Salmonella enterica serovar 4, [5],12: i: - in Europe: a new pandemic strain? Eurosurveillance, Stockholm, v. 15, n. 22, 2010. 
LOUREIRO, E. C. B.; MARqUES, N. D. B.; RAMOS, F.L.P.; REIS, E. M. F.; RODRIGUES, D. P.; HOFER, E. Salmonella serovars of human origin identified in Pará State, Brazil from 1991 to 2008. Revista Pan-Amazônica de Saúde, Manaus, v. 1, n. 1, p. 93-100, 2010.

NATIONAL COMMITTEE FOR CLINICAL LABORATORY STANDARDS NCCLS. Performance standards for antimicrobial susceptibility testing: twelvth informational supplement. National Committee For Clinical Laboratory Standards M100-S12, v. 22, n. 1, Wayne, 2002.

O'CONNOR, K.; FLETCHER, S. A.; CSONKA, L. N. Increased expression of Mg (2+) transport proteins enhances the survival of Salmonella enterica at high temperature. Proc Natl Acad Sci U S A, v. 106, n. 41, p. 17522-7. 2009.

ORGANIZAÇÃO INTERNACIONAL DE EPIZOOTIAS. Salmonellosis. Manual of diagnostic tests and vaccines for terrestrial animals, 5. ed., 2004. Available in: $<$ http://oie.int>Accessed in: oct. 2011.

PACHECO, M. T. N. Salmonella spp. em rebanho comercial de suínos e em suas carcaças processadas no frigorífico. 2009. 69f. Dissertation (Master degree in Veterinary Sciences) - Universidade Federal de Uberlândia, Uberlândia, MG, 2009.

SEIXAS, F. N.; TOCHETTO, R.; FERRAZ, S. M. Presença de Salmonella spp. em carcaças suínas amostradas em diferentes pontos da linha de processamento. Ciência Animal Brasileira, Goiânia, v. 10, n. 2, p. 634-640, 2009.

SPRICIGO, D. A.; MATSUMOTO, S. R.; ESPÍNDOLA, M. L.; VAZ, E. K.; FERRAZ, S. M. Prevalência e perfil de resistência a antimicrobianos de sorovares de Salmonella isolados de lingüiças suínas tipo frescal em Lages, SC. Arquivo Brasileiro de Medicina Veterinária e Zootecnia, Belo Horizonte, v. 60, n. 2, p. 517-520, 2008. 
TESSMANN, C.; ZOCCHE, F.; LIMA, A. S.; BASSANI, M.; LOPES, G. V.; SILVA, W. P. Ocorrência e Perfil de sensibilidade a antibióticos de Salmonella spp. isolada em cortes de carne suína comercializados em feiras livres de Pelotas (RS). Boletim Centro de Pesquisa de Processamento de Alimentos, Curitiba, v. 26, n. 2, p. 307-313, 2008.

WRAY, C. W.; SOJKA, W. J. Reviews of the progress of dairy science: bovine salmonellosis. Journal of Dairy Science, Champaign, v. 44, n. 2, p. 383-425, 1977. 